Original Research Paper

\title{
Seasonal Abundance and Species Composition of Nephotettix spp., in Endemic and Non-Endemic Areas of Rice Tungro Virus Disease in South Sulawesi Province, Indonesia
}

\author{
Andi Nasruddin, Muhammad Danial Rahim and Fatahuddin \\ Department of Plant Pests and Diseases, Faculty of Agriculture, Hasanuddin University, Makassar 90245, Indonesia
}

\author{
Article history \\ Received: 03-07-2016 \\ Revised: 27-08-2016 \\ Accepted: 01-09-2016 \\ Corresponding Author: \\ Andi Nasruddin \\ Department of Plant Pests and \\ Diseases, Faculty of \\ Agriculture, Hasanuddin \\ University, Makassar 90245, \\ Indonesia \\ Email: andinasruddin@yahoo.com
}

\begin{abstract}
Rice tungro disease is semi-persistently transmitted by five species of leafhopper. Nephotettix virescens Distant and N. nigropictus Stal. (Homoptera: Cicadellidae) are predominant species in South Sulawesi with vectoring efficiencies of 83 and $27 \%$, respectively. Relative composition of those species affects the RTV incidence in the field. The purpose of the study was to determine the presence and abundance of those species in RTV-endemic and non-RTV-endemic areas in South Sulawesi. The presence of both species at different altitudinal levels was also determined. The results showed that $N$. virescens was present in both RTV-endemic and non-RTV-endemic areas. In RTV-endemic area, $N$. virescens was the only species found. Higher number of $N$. nigropictus existed in non-endemic area with less intensive use of insecticide than in non-endemic area with intensive use of insecticides. Nephotettix virescens was found in the low (< $100 \mathrm{~m}$ above sea level) and mid (500-700 m) altitudes but not in the high elevation (> $1000 \mathrm{~m}$ ). In the high altitude, only $N$. nigropictus existed. This species was also present in the mid and lower levels in non-RTV-endemic area with lower intensity of insecticide use.
\end{abstract}

Keywords: Nephotettix virescens, Nephotettix nigropictus, Tungro, Rice, Leafhopper

\section{Introduction}

Tungro disease caused by Rice Tungro Virus (RTV) is the most devastating viral disease of rice in South and South East Asian countries. During the period of 19691983 the disease damaged 168,000 ha of rice in Indonesia; 100,000 ha of which occurred in the Province of South Sulawesi alone during the period of 1972-1975 (Hibino, 1987); and by 1992 the national figure had risen to 243,693 ha (DBPT, 1992).

Rice tungro virus is transmitted by five species of rice leafhopper, Nephotettix virescens Distant, $N$. nigropictus Stal., N. malayanus Ishihara et Kawase, $N$. parvus Ishihara et Kawase and Recilia dorsalis Motschulsky in semi-persistent fashion (Hibino, 1983; Siwi et al., 1987). Transmission efficiency of tungro virus varies among the vector species. Percentages of active transmitter were $83,27,0-16 \%$, about $42 \%$ and about $7 \%$ in $N$. virescens, $N$. nigropictus, $R$. dorsalis, $N$. malayanus and N. parvus, respectively (Ling, 1975).

Nephotettix virescens was the only vector species collected from rice fields in South Sulawesi (Siwi et al.,
1987) when RTV epidemics occurred throughout the province. However, Widiarta et al. (2001) reported that $N$. nigropictus was found dominant on rice in Subdistrict Bantimurung, Maros. Since $N$. virescens is the most efficient RTV vector, its composition in the field is closely related to the extent of tungro disease (Suzuki et al., 1992). However, no information is available on the current distribution and composition of both vector species in the province.

For the last 10 years, RTV occurred periodically (every 2-3 years) only in certain areas in South Sulawesi (the Districts of Bantaeng, Pinrang and Sidenreng Rappang); but in most parts of the province, the disease occurs sporadically with limited damage to crops (Pakki and Bastian, 2008). Bantaeng, Pinrang and Sidenreng Rappang are considered RTV-endemic area and the rest of the province is considered non RTVendemic area. Therefore, the objective of the current study was to elucidate the abundance and the relative composition of $N$. virescens and $N$. nigropictus in RTVendemic and non-endemic areas in South Sulawesi. In 
addition, the presence of both species at different altitudinal levels in the province was also determined.

\section{Materials and Methods}

\section{Seasonal Abundance of Leafhoppers}

Seasonal abundances of $N$. viresvens and $N$. nigropictus were monitored using biweekly sweep net sampling during two consecutive seasons, the rainy planting season (January to April 2012) and dry planting season (June-September 2012). Sampling sites were placed into two categories: (1) RTV-endemic area (Districts of Bantaeng, Pinrang and Sidenreng Rappang) and (2) non-RTV-endemic area (Districts of Maros, Pangkajene Kepulauan, Barru, Gowa, Takalar and Jeneponto) (Pakki and Bastian, 2008). During the study, in RTV-endemic area, percentages of rice hills samples showing RTV symptoms were 1, 2 and 2\% in Districts of Bantaeng, Pinrang and Sidenreng Rappang, respectively. While in non-RTV endemic area, none of the plant samples were infected by RTV $(n=100)$. The non-RTV-endemic area was further classified into two sub-areas: Sub-area with more intensive use of insecticides (Districts of Maros, Pangkajene Kepulauan and Barru) and area with less intensive use of insecticides (Districts of Gowa, Takalar and Jeneponto) with 4-6 and 0-2 insecticide applications per season, respectively (Fig. 1).

The sub-areas were based on our survey results on the frequency of insecticide applications in all survey sites (data not shown). Insecticides were used intensively (4-6 applications per season) in all RTV-endemic areas.

In each district, 3 to 4 samples of 20 sweeps each were collected using a $37-\mathrm{cm}$ net hoop with $1.2 \mathrm{~m}$ wooden handle. Rainfall patterns are different between the RTV-endemic and non-RTV-endemic areas. In nonRTV-endemic area the rainy season occurs from October to May; whereas in RTV-endemic area, the rainy season occurs from April to July in Sidenreng Rappang and Bantaeng and November to July in Pinrang (Climatology Station, Maros 2013). The samples were collected from the farmers' rice fields, 5-15 km apart. Sampled fields were situated along the provincial main road, about 100$200 \mathrm{~m}$ off the road to avoid the road effects. Leafhoppers collected from each location were placed into a 1-1 plastic jar containing a small chloroform-saturated cotton ball to knock the leafhoppers down. The leafhoppers were then brought back to our laboratory for identification, sorting and counting. Because the age and cultivar of rice plant affect the leafhopper population level (Widiarta et al., 1997), 2-3 weeks old rice cv. Ciherang (the most commonly planted cultivar in the study sites) was chosen for the sampling in all study locations. Leafhopper samples were collected until the onset of panicles.

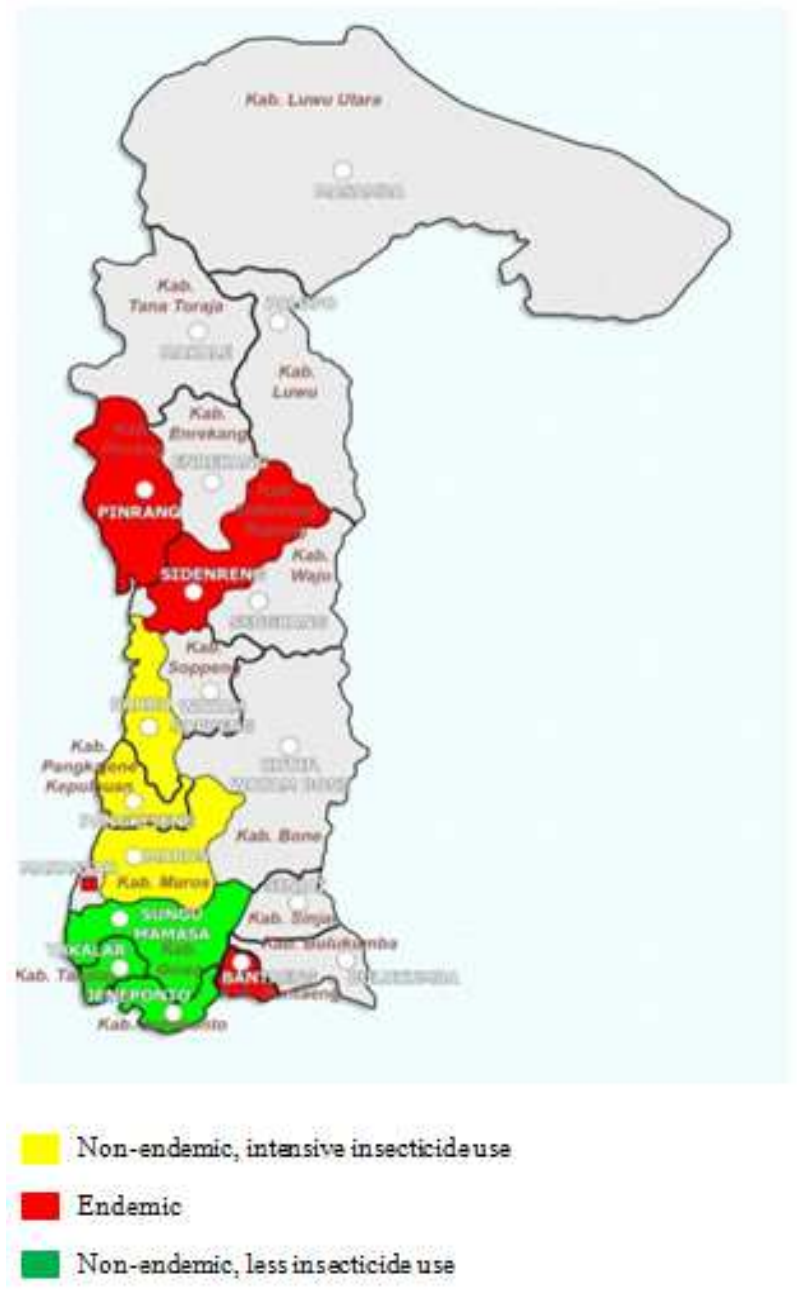

Fig. 1. Survey locations for the abundance and species composition of Nephotettix spp.

\section{Number of Leafhoppers at Different Altitudes}

Leafhopper samples were also collected from farmers' rice fields located at different altitudinal levels: Low $(<100)$, middle $(300-600 \mathrm{~m})$ and high $(>$ $1000 \mathrm{~m}$ ) above the sea level. At each altitudinal level, leafhopper samples of 20 sweeps were collected from five rice fields using a $37-\mathrm{cm}$ sweep net. Leafhoppers collected from each location were placed into a 1-1 plastic jar containing a small chloroform-saturated cotton ball then brought back to our lab for identification, sorting and counting. Sampling dates were May 5, June 5 and July 6, 2012.

\section{Data Analysis}

Data of the field surveys were transformed using the $\log 10(\mathrm{x}+1)$ transformation before being subjected to a one-way ANOVA across the RTV-endemic and nonRTV endemic locations. Means were separated using 
Tukey's HSD test (BIOSTAT, 2009). Overall numbers of leafhoppers during the rainy and dry seasons were compared using a T-test at 5\% level.

\section{Results}

\section{Seasonal Abundance of Nephotettix spp.}

Nephotettix virescens was present in both RTV endemic and non-RTV endemic areas during the rainy season (Table 1) and dry season (Table 2). In the rainy season the number of $N$. virescens in non endemic area with less intensive use of insecticide was significantly higher $(\mathrm{p}<0.05)$ than those in the endemic area and non-endemic area with more intensive use of insecticide (Table 1).

Similar trend was observed during the dry season but due to the low population level, no significant differences were detected among sampling sites ( $>0.05)$ (Table 2).

Overall, the number of $N$. virescens collected during the rainy season was higher than during the dry season $(p<0.05)$. This species was the only rice leafhopper species found in the endemic area and non-endemic area with more intensive use of insecticide, except in Maros, one individual of $N$. nigropictus was collected from the field. However, in non-endemic area with less insecticide use both species were found. The percentage of $N$. virescens varied in different locations, from 9 to $41 \%$ with an average of $27 \%$ (Fig. 2).

Nephotettix nigropictus was found in non-endemic area with less use of insecticide and one of the districts in the endemic area (Bantaeng) with negligible population size in the rainy season (Table 3).

The number of $N$. nigropictus in non endemic area with less intensive use of insecticide was significantly higher $(\mathrm{p}<0.05)$ than those in the endemic area and non endemic area with more intensive use of insecticide. However, during the dry season, $N$. nigropictus was only present in non-endemic area with less use of insecticide (Table 4). There were no significant differences among the sampling sites in the number of $N$. nigropictus $(\mathrm{p}>0.05)$. The number of $N$. nigropictus collected in the rainy season was higher than in the dry season $(\mathrm{p}<0.05)$.

The abundance of these two rice green leafhopper species in all sites increased from January (2-3 weeks after transplanting) and reached their peaks in mid March (6-7 weeks after transplanting) during the rainy season. Similar trend occurred during the dry season with lower population density.

\section{Species Composition of Nephotettix spp. at Different Altitudes}

Nephotettix nigropictus was present at all altitudinal levels on each sampling date. At low altitude $(<100 \mathrm{~m})$, the species was only present in non RTV endemic area with less insecticide use. Nephotettix virescens was collected from both low and mid altitudinal levels on all sampling dates with 24 and $60 \%$ of the total rice leafhopper population, respectively. At high altitude $(>1,000 \mathrm{~m}) \mathrm{N}$. nigropictus was the only rice leafhopper species present during the survey (Fig. 3).

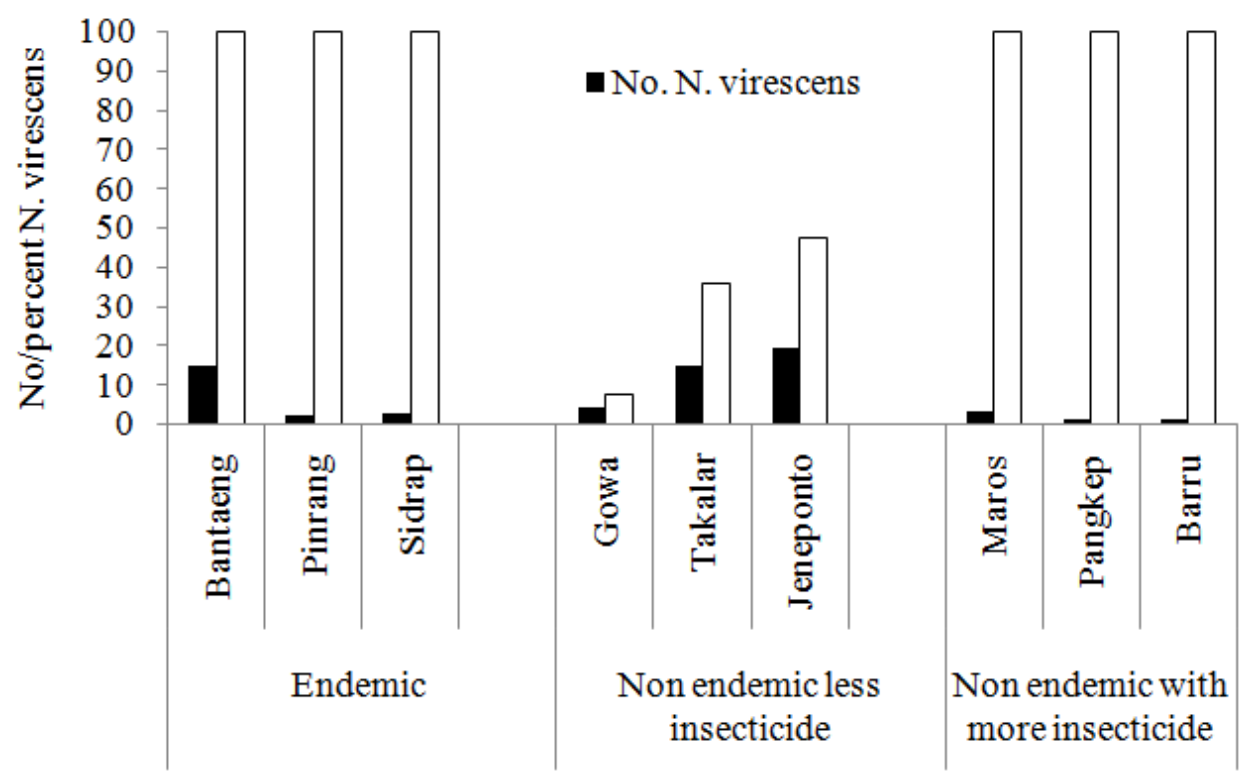

Fig. 2. Number and percent of $N$. virescens per 20 sweeps in various sampling locations: RTV endemic area, non-RTV endemic area with intensive use of insecticide and non-RTV endemic area with less intensive use of insecticide 


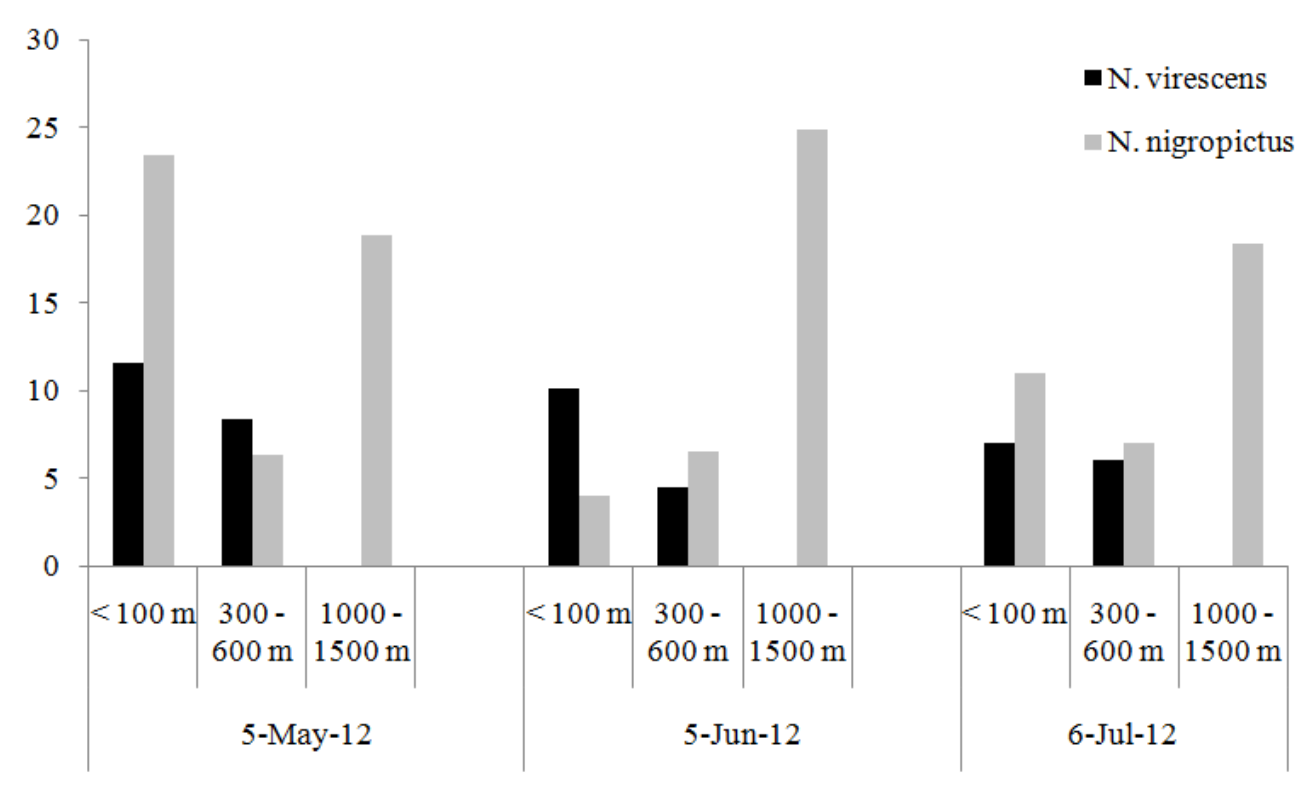

Fig. 3. Average number of $N$. virescens and N. nigropictus per 20 sweeps at different altitudes $(<100,300-600$ and 1,000-1,500 m asl) in South Sulawesi

Table 1. Average number of adult $N$. virescens per 20 sweeps on each biweekly sampling date at various locations in Rice Tungro Virus (RTV) endemic and non-endemic areas in South Sulawesi during the rainy planting season (January to April 2012)

\begin{tabular}{|c|c|c|c|c|c|}
\hline \multirow[b]{2}{*}{ RTV Status } & \multirow[b]{2}{*}{ Location } & \multicolumn{4}{|c|}{ No. leafhoppers (mean \pm SE) } \\
\hline & & 21 Jan 2012 & 4 Feb 2012 & 18 Feb 2012 & 3 Mar 2012 \\
\hline \multirow[t]{3}{*}{ Endemic } & Bantaeng & $5.5 \pm 0.47 \mathrm{ab}$ & $8.0 \pm 0.78 \mathrm{ab}$ & $34.0 \pm 8.57 \mathrm{a}$ & $12.2 \pm 0.43 \mathrm{a}$ \\
\hline & Pinrang & $0.0 \pm 0.00 \mathrm{a}$ & $2.2 \pm 0.49 \mathrm{a}$ & $4.5 \pm 0.68 \mathrm{a}$ & $3.5 \pm 0.37 \mathrm{a}$ \\
\hline & Sidrap & $2.0 \pm 0.12 \mathrm{a}$ & $0.0 \pm 0.00 \mathrm{a}$ & $2.7 \pm 0.42 \mathrm{a}$ & $3.5 \pm 1.11 \mathrm{a}$ \\
\hline \multirow[t]{6}{*}{ Non-endemic } & Gowa $^{1}$ & $9.0 \pm 0.52 \mathrm{ab}$ & $13.4 \pm 0.89 \mathrm{~b}$ & $17.6 \pm 1.62 \mathrm{~b}$ & $11.6 \pm 1.04 \mathrm{~b}$ \\
\hline & Takalar $^{1}$ & $13.0 \pm 1.01 \mathrm{~b}$ & $17.8 \pm 1.73 \mathrm{~b}$ & $36.0 \pm 1.49 \mathrm{c}$ & $23.2 \pm 1.36 \mathrm{c}$ \\
\hline & Jeneponto $^{1}$ & $14.0 \pm 1.17 \mathrm{~b}$ & $26.0 \pm 1.49 \mathrm{c}$ & $44.0 \pm 1.25 \mathrm{c}$ & $34.4 \pm 4.40 \mathrm{~d}$ \\
\hline & $\operatorname{Maros}^{2}$ & $0.0 \pm 0.00 \mathrm{a}$ & $1.5 \pm 0.32 \mathrm{a}$ & $7.7 \pm 0.42 \mathrm{a}$ & $3.5 \pm 0.25 \mathrm{a}$ \\
\hline & Pangkep $^{2}$ & $0.0 \pm 0.00 \mathrm{a}$ & $0.0 \pm 0.00 \mathrm{a}$ & $3.7 \pm 0.42 \mathrm{a}$ & $0.7 \pm 0.16 \mathrm{a}$ \\
\hline & Barru $^{2}$ & $0.0 \pm 0.00 \mathrm{a}$ & $0.2 \pm 0.08 \mathrm{a}$ & $2.2 \pm 0.15 \mathrm{a}$ & $1.7 \pm 0.26 \mathrm{a}$ \\
\hline
\end{tabular}

Numbers within a column followed by the same letter are not significantly different by Tukey's test $(\mathrm{P}=0.05)$.

${ }^{1}$ Less intensive use of insecticide

${ }^{2}$ Intensive use of insecticide

Table 2. Average number of adult $N$. virescens per 20 sweeps on each biweekly sampling date at various locations in Rice Tungro Virus (RTV) endemic and non-endemic areas in South Sulawesi during the dry planting season (June to September 2012)

\begin{tabular}{|c|c|c|c|c|c|}
\hline \multirow[b]{2}{*}{ RTV Status } & \multirow[b]{2}{*}{ Location } & \multicolumn{4}{|c|}{ No. leafhoppers $($ mean \pm SE) } \\
\hline & & 14 June 2012 & 28 June 2012 & 12 July 2012 & 26 July 2012 \\
\hline \multirow[t]{3}{*}{ Endemic } & Bantaeng & $1.00 \pm 0.23$ & $1.50 \pm 0.28$ & $8.00 \pm 0.40$ & $4.50 \pm 0.28$ \\
\hline & Pinrang & $0.00 \pm 0.00$ & $0.50 \pm 0.16$ & $2.50 \pm 0.28$ & $2.50 \pm 0.16$ \\
\hline & Sidrap & $0.00 \pm 0.00$ & $0.00 \pm 0.00$ & $2.50 \pm 0.37$ & $0.50 \pm 0.16$ \\
\hline \multirow[t]{6}{*}{ Non-endemic } & Gowa $^{1}$ & $0.00 \pm 0.00$ & $0.50 \pm 0.16$ & $3.00 \pm 0.57$ & $4.50 \pm 0.16$ \\
\hline & Takalar ${ }^{1}$ & $0.25 \pm 0.14$ & $2.50 \pm 0.16$ & $5.25 \pm 0.35$ & $3.50 \pm 0.97$ \\
\hline & Jeneponto $^{1}$ & $1.00 \pm 0.23$ & $3.00 \pm 0.74$ & $3.50 \pm 0.28$ & $1.25 \pm 0.14$ \\
\hline & Maros $^{2}$ & $0.00 \pm 0.00$ & $0.00 \pm 0.00$ & $1.50 \pm 0.16$ & $1.50 \pm 0.11$ \\
\hline & Pangkep ${ }^{2}$ & $0.00 \pm 0.00$ & $0.00 \pm 0.00$ & $3.25 \pm 0.36$ & $1.50 \pm 0.16$ \\
\hline & Barru $^{2}$ & $0.00 \pm 0.00$ & $0.25 \pm 0.14$ & $2.50 \pm 0.15$ & $2.50 \pm 0.28$ \\
\hline
\end{tabular}

No significant differences among sample locations in the number of $N$. virescens $(\mathrm{p}>0.05)$.

${ }^{1}$ Less intensive use of insecticide

${ }^{2}$ Intensive use of insecticide 
Table 3. Average number of adult $N$. nigropictus per 20 sweeps on each biweekly sampling date at various locations in Rice Tungro Virus (RTV) endemic and non-endemic areas in South Sulawesi during the rainy planting season (January to April 2012)

\begin{tabular}{|c|c|c|c|c|c|}
\hline \multirow[b]{2}{*}{ RTV Status } & \multirow[b]{2}{*}{ Location } & \multicolumn{4}{|c|}{ No. leafhoppers (mean $\pm \mathrm{SE}$ ) } \\
\hline & & 21-Jan-12 & 4-Feb-12 & 18-Feb-12 & 3-Mar-12 \\
\hline \multirow[t]{3}{*}{ Endemic } & Bantaeng & $0.00 \pm 0.00 \mathrm{a}$ & $0.20 \pm 0.13 \mathrm{a}$ & $0.60 \pm 0.21 \mathrm{a}$ & $0.00 \pm 0.00 \mathrm{a}$ \\
\hline & Pinrang & $0.00 \pm 0.00 \mathrm{a}$ & $0.00 \pm 0.00 \mathrm{a}$ & $0.00 \pm 0.00 \mathrm{a}$ & $0.00 \pm 0.00 \mathrm{a}$ \\
\hline & Sidrap & $0.00 \pm 0.00 \mathrm{a}$ & $0.00 \pm 0.00 \mathrm{a}$ & $0.00 \pm 0.00 \mathrm{a}$ & $0.00 \pm 0.00 \mathrm{a}$ \\
\hline \multirow[t]{6}{*}{ Non-endemic } & Gowa $^{1}$ & $1.00 \pm 0.35 \mathrm{a}$ & $5.75 \pm 1.64 \mathrm{ab}$ & $44.25 \pm 5.14 \mathrm{~d}$ & $17.00 \pm 1.19 \mathrm{~b}$ \\
\hline & Takalar $^{1}$ & $0.25 \pm 0.14 \mathrm{a}$ & $11.75 \pm 2.92 b$ & $24.00 \pm 5.95 \mathrm{c}$ & $24.75 \pm 4.52 b$ \\
\hline & Jeneponto $^{1}$ & $0.00 \pm 0.00 \mathrm{a}$ & $4.25 \pm 0.81 \mathrm{ab}$ & $12.00 \pm 2.29 \mathrm{~b}$ & $22.00 \pm 6.89 b$ \\
\hline & Maros $^{2}$ & $0.00 \pm 0.00 \mathrm{a}$ & $0.00 \pm 0.00 \mathrm{a}$ & $0.00 \pm 0.00 \mathrm{a}$ & $0.20 \pm 0.00 \mathrm{a}$ \\
\hline & Pangkep $^{2}$ & $0.00 \pm 0.00 \mathrm{a}$ & $0.00 \pm 0.00 \mathrm{a}$ & $0.00 \pm 0.00 \mathrm{a}$ & $0.00 \pm 0.00 \mathrm{a}$ \\
\hline & Barru $^{2}$ & $0.00 \pm 0.00 \mathrm{a}$ & $0.00 \pm 0.00 \mathrm{a}$ & $0.00 \pm 0.00 \mathrm{a}$ & $0.00 \pm 0.00 \mathrm{a}$ \\
\hline
\end{tabular}

Numbers within a column followed by the same letter are not significantly different by Tukey's test $(\mathrm{P}=0.05)$.

${ }^{1}$ Less intensive use of insecticide

${ }^{2}$ Intensive use of insecticide

Table 4. Average number of adult $N$. nigropictus per 20 sweeps on each biweekly sampling date at various locations in Rice Tungro Virus (RTV) endemic and non-endemic areas in South Sulawesi during the dry planting season (June to September 2012)

\begin{tabular}{|c|c|c|c|c|c|}
\hline \multirow[b]{2}{*}{ RTV Status } & \multirow[b]{2}{*}{ Location } & \multicolumn{4}{|c|}{ No. leafhoppers $($ mean \pm SE) } \\
\hline & & 14-Jun-12 & 28-Jun-12 & 12-Jul-12 & 26-Jul-12 \\
\hline \multirow[t]{3}{*}{ Endemic } & Bantaeng & $0.00 \pm 0.00$ & $0.00 \pm 0.00$ & $0.00 \pm 0.00$ & $0.00 \pm 0.00$ \\
\hline & Pinrang & $0.00 \pm 0.00$ & $0.00 \pm 0.00$ & $0.00 \pm 0.00$ & $0.00 \pm 0.00$ \\
\hline & Sidrap & $0.00 \pm 0.00$ & $0.00 \pm 0.00$ & $0.00 \pm 0.00$ & $0.00 \pm 0.00$ \\
\hline \multirow[t]{6}{*}{ Non-endemic } & Gowa $^{1}$ & $0.00 \pm 0.00$ & $0.00 \pm 0.00$ & $0.00 \pm 0.00$ & $4.50 \pm 0.16$ \\
\hline & Takalar $^{1}$ & $0.00 \pm 0.00$ & $0.00 \pm 0.00$ & $3.20 \pm 0.35$ & $3.50 \pm 0.97$ \\
\hline & Jeneponto $^{1}$ & $0.00 \pm 0.00$ & $1.00 \pm 0.00$ & $4.50 \pm 0.28$ & $5.25 \pm 0.14$ \\
\hline & Maros $^{2}$ & $0.00 \pm 0.00$ & $0.00 \pm 0.00$ & $0.00 \pm 0.00$ & $0.00 \pm 0.00$ \\
\hline & Pangkep $^{2}$ & $0.00 \pm 0.00$ & $0.00 \pm 0.00$ & $0.00 \pm 0.00$ & $0.00 \pm 0.00$ \\
\hline & Barru $^{2}$ & $0.00 \pm 0.00$ & $0.00 \pm 0.00$ & $0.00 \pm 0.00$ & $0.00 \pm 0.00$ \\
\hline
\end{tabular}

No significant differences among sample locations in the number of $N$. nigropictus $(\mathrm{p}>0.05)$.

${ }^{1}$ Less intensive use of insecticide

${ }^{2}$ Intensive use of insecticide

\section{Discussion}

Nephotettix virescens was present in both RTV endemic and non-RTV endemic areas in South Sulawesi. Similar results have been reported in Java that $N$. virescens was dominant in both RTV endemic and nonendemic areas (Supriyadi, 2004). Overall numbers of both species were higher in the areas with less insecticide use than in the areas with intensive use of insecticides. Two insecticide applications per season could effectively suppress the leafhopper population (Pakki and Bastian, 2008); however, in the RTV endemic area farmers apply insecticide up to six times during the planting season to control other insect pests, such as rice stem borer and rice stink bug.

Nephotettix nigropictus was found in non RTVendemic area with less intensive use of insecticides (Table 2). However, the species was not found in non RTV-endemic area with more insecticide applications. $N$. nigropictus was also present in RTV endemic area (Bantaeng) with very low population. The results suggested that $N$. nigropictus is probably more susceptible to insecticide use than $N$. virescens.
In RTV-endemic and non-RTV-endemic areas with more insecticide use, all leafhoppers caught was $N$. virescens. Whereas in non-endemic area with less intensive use of insecticide, $40-60 \%$ of all green leafhoppers collected was $N$. nigropictus. $N$. virescens was the only rice green leafhopper species found in the province (Siwi et al., 1987); however, Widiarta et al. (2001) reported that $N$. nigropictus was dominant in Subdistrict of Bantimurung, District of Maros. Widiarta et al. (2001) further showed that rice cultivars known to be resistant against $N$. virescens were susceptible to $N$. nigropictus. Besides that, Siwi and Damayanti (1991) reported that when both species were placed on rice plants in a cage; N. nigropictus was more competitive than $N$. virescens. Our results showed that $N$. nigropictus distribution has expanded in the province, especially in the areas where insecticide use was less intensive.

In non RTV-endemic area with less use of insecticide, $N$. virescens populations were higher but RTV incidence is just sporadic (Pakki and Bastian, 2008). This is probably caused by the unavailability of inoculum sources in the fields. Rice tungro virus can cause serious damages if the inoculum sources are available in the field even 
when the vector's population was low (Widiarta, 2004). Besides that, the number of $N$. virescens active transmitter in the endemic area was higher than that in the nonendemic area (Supriyadi, 2004).

Nephotettix virescens was collected from low and mid altitudes but not from high altitude; while $N$. nigropictus was the only rice green leafhopper species found at high altitude (Fig. 3). This at least partly explains why RTV in the high elevation is not important in the survey locations. Nephotettix nigropictus is less effective vector species of RTV with efficiency of $27 \%$ (Ling, 1975). At the low level (<100 m asl) with less use of insecticides and mid-level (300-600 m abs) both species were present but both locations were designated as non RTV-endemic areas.

To the best of our knowledge, this is the first record of the presence of $N$. nigropictus in low elevations in the Districts of Gowa, Takalar and Jeneponto. Nephotettix virescens was the only rice green leafhopper associated with rice in South Sulawesi (Siwi et al., 1987). In 2001 $N$. nigropictus was reported predominant in one subDistrict of Bantimurung (District of Maros, 50-100 m asl) (Widiarta et al., 2001). However, in the current study $N$. nigropictus was found with negligible number in the district during the rainy season and none was found during dry season. The expanding geographical distribution of $N$. nigropictus (less efficient vector) in the province is probably one of the reasons why the RTV is decreasingly important in the region with limited number of locations remaining designated as endemic area.

Our results revealed that $N$. virescens was predominant in RTV-endemic area, which encompasses only limited area (Districts of Bantaeng, Pinrang and Sidenreng Rappang). One of the recommended control measures of RTV is the rotation of resistant cultivars used against the principal vector, $N$. virescens. The main constraint of applying the control tactic is the availability of enough seeds of the recommended resistant cultivars for a particular planting season for all rice planting areas in the province, totaling 889,232 ha (BPS, 2011). The study results suggested that the amount of resistant seeds needed could be substantially reduced by focusing its use only on those endemic areas. Widiarta et al. (2001) reported that cultivar resistance against $N$. virescens is controlled by different genes from those against $N$. nigropictus. Therefore, it is necessary to identify cultivars with resistant genes against $N$. nigropictus and such cultivars could be recommended for the non RTV-endemic area where $N$. nigropictus is present and dominant.

\section{Conclusion}

Two species of rice green leafhopper were found in the study sites, $N$. virescens and $N$. nigropictus. Both species were more abundant during the rainy season than the dry season. Nephotettix virescens was found in both RTV-endemic and non RTV-endemic areas, while, $N$. nigropictus was found in non RTV-endemic area only. Nephotettix virescens was found in low and mid elevations where insecticides were used intensively and less intensively. Nephotettix nigropictus, however, was found in all elevations. In low altitude, it was found only in the areas where insecticides were used less intensively. To the best of our knowledge, this is the first record of the presence of $N$. nigropictus in low elevations in the Districts of Gowa, Takalar and Jeneponto.

\section{Acknowledgement}

We express our sincere appreciation to the numerous rice farmers who allowed us to use their rice fields for the study. We also thank Muhammad Said Baco for the technical assistance. The study was funded by the Directorate General of Higher Education, Ministry of the National Education and Culture, Republic of Indonesia under "the Higher Education Excellence Research Program (Penelitian Unggulan Perguruan Tinggi)" administered by the Research and Extension Institute of Hasanuddin University, No: 591/UN4.20/PL.09/2012.

\section{Authors' Contributions}

Andi Nasruddin: Coordinated research activities, performed data analyses and prepared the manuscript.

Muhammad Danial Rahim: Designed research plan and organized data collection in RTV endemic areas.

Fatahuddin: Designed research plan and organized data collection in non-RTV endemic areas.

\section{Ethics}

This article is an original research paper and contains unpublished data, except the abstract is available in the electronic repository system, Hasanuddin University (http://repository.unhas.ac.id/handle/123456789/6309) as required by the institution. The corresponding author confirms that no ethical issues will occur due to the publication of the manuscript.

\section{References}

BPS, 2011. Statistik Sulawesi Selatan. Badan Pusat Statistik.

BIOSTAT, 2009. Statistical analysis program. AnalystSoft, Inc. www.analystsoft.com

DBPT, 1992. Tungro dan Wereng Hijau. Direktorat Bina Perlindungan Tanaman.

Hibino, H., 1983. Transmission of tungro associated viruses and rice waika virus from doubly or singly infected plants by leafhopper vectors. Plant Disease, 67: 774-777. 
Hibino, H., 1987. Rice tungro virus disease: Current research and prospects. Proceedings of the Workshop on Rice Tungro Virus, Sept. 24-27, Maros Research Institute for Food Crops.

Ling, K.C., 1975. Rice Virus Diseases. 1st Edn., The IRRI, Los Banos, Philippines, pp: 106.

Pakki, S. and A. Bastian, 2008. Dinamika Sebaran Penyakit Tungro pada Beberapa Wilayah Sentra Produksi Padi. Balai Penelitian Tanaman Serealia, Maros.

Siwi, S.S. and D. Damayanti, 1991. Proceedings of a seminar of research outcomes of bogor research institute of food crops 1990. Balai Penelitian Tanaman Pangan Bogor.

Siwi, S.S., A. Kartoharjono, S. Harnoto and A. Diratmaja, 1987. The green leafhopper, genus Nephotettix Matsumura. Proceedings of the Workshop on the Rice Tungro, (WRT' 87), Research Institute of Food Crops.

Supriyadi, 2004. Population characteristics of the green leafhopper Nephotettix virescens (Hemiptera: Cicadellidae) in the endemic and non endemic areas of rice tungro disease. Indonesian Agr. Res. Dev.
Suzuki, Y., Soeroto and S.S Siwi, 1992. Tungro dan Wereng Hijau. Laporan akhir kerja sama Indonesia-Jepang. Dirjen Pertanian Tanaman Pangan, Jakarta.

Widiarta, I.N., 2004. Status dan program penelitian pengendalian terpadu penyakit tungro. Prosiding seminar nasional status program penelitian tungro mendukung keberlanjutan produksi padi nasional. Makassar.

Widiarta, I.N., D. Kusdiaman and Koesnang, 2001. Fenomena dan faktor yang mempengaruhi pergeseran dominasi species wereng hijau (Nephotettix spp.). Prosiding Seminar Nasional III Perhimpunan Entomologi Indonesia, Bogor.

Widiarta, I.N., Yulianto and M. Muchsin, 1997. Distribution status of rice tungro disease in West Java, Indonesia. J. Plant Prot., 3: 23-31. 